\title{
A bacterial disease of hellebore caused by Pseudomonas viridiflava in New Zealand
}

\author{
Robert K. Taylor • Megan K. Romberg • \\ Brett J. R. Alexander
}

Received: 3 February 2011 / Accepted: 27 April 2011 /Published online: 6 May 2011

(C) Australasian Plant Pathology Society Inc. 2011

\begin{abstract}
Pseudomonas viridiflava is reported causing a disease of hellebore (Helleborus $\times$ hybridus) in New Zealand. The bacterium was isolated from diseased plants exhibiting distinct symptoms consisting of black leaf spots, necrotic petal and stem lesions. P. viridiflava was identified on the basis of biochemical and molecular tests and confirmed as the causal agent by fulfilling Koch's postulates.
\end{abstract}

Keywords Pseudomonas viridiflava $\cdot$ Hellebore

Hellebores are grown in New Zealand as an ornamental plant and as a commercial crop to supply cut flowers to local and export markets. The most popular hellebores are Helleborus orientalis and its hybrids $(H . \times$ hybridus $)$. Hellebores are mainly propagated in shade houses and watered by drip irrigation.

In August 2010, diseased hellebore plants (H. $\times$ hybridus Double White) were observed in a nursery in Tauranga, New Zealand. Symptoms developed after several days of moderate rainfall and more than $90 \%$ of the plants were affected, resulting in unsuitability for sale. Symptoms consisted of circular, black leaf spots which were 1.5$2 \mathrm{~mm}$ in diameter, black stem lesions and dry, grey to brown lesions with distinct margins on the flower petals (Fig. 1). The symptoms were different from those caused by other leaf-spotting pathogens of hellebore such as the fungus Coniothyrium sp. and the bacterium Xanthomonas sp. (Gleason et al. 2009).

R. K. Taylor $(\triangle) \cdot$ M. K. Romberg $\cdot$ B. J. R. Alexander Plant Health and Environment Laboratory,

Ministry of Agriculture and Forestry,

PO Box 2095, Auckland 1140, New Zealand

e-mail: robert.taylor@maf.govt.nz
Saline suspensions of macerated diseased leaf, petal and stem tissues were streaked onto King's B medium (King et al. 1954) and pale yellow, fluorescent bacterial colonies were consistently growing following $48 \mathrm{~h}$ incubation at $25^{\circ} \mathrm{C}$. All isolates were Gram negative and were levan, oxidase and arginine dehydrolase negative. They all produced a hypersensitive reaction on tobacco leaves after $24-36 \mathrm{~h}$ and showed pectolytic activity on potato tuber slices. The bacterium was identified as $P$. viridiflava on the basis of these biochemical tests and is in group II of the LOPAT determinative scheme of Lelliott et al. (1966). The housekeeping gene gyrB (Sarkar and Guttman 2004) was amplified from two isolates (ICMP 18563, 18564), producing a $600 \mathrm{bp}$ amplicon. BLASTn analysis of the $\operatorname{gyr} B$ amplicons showed that the region was $99.0-99.8 \%$ homologous to P. viridiflava sequences in GenBank, with highest homology to accessions AY606756 and AY606738. Pseudomonas viridiflava was isolated consistently from leaf, petal and stem tissue adjacent to leaf spots, petal and stem lesions. Pathogenicity tests with two selected isolates of $P$. viridiflava (ICMP 18563, 18564) were performed on hellebore $(H . \times$ hybridus $)$ cut flowers, young detached leaves and petals. Each isolate was inoculated onto three detached petals and leaves by placing $20 \mu$ of bacterial suspension $\left(10^{7} \mathrm{cfu} / \mathrm{mL}\right)$ on the surface and pricking through the drops using sterile needles. After inoculation, the detached petals and leaves were kept in Petri dishes lined with moist filter paper, incubated at $25^{\circ} \mathrm{C}$ and checked daily for symptoms. Three healthy cut flowers with stems submerged in flasks of water were inoculated per isolate in a similar manner, enclosed in clear polyethylene bags and incubated at $25^{\circ} \mathrm{C}$. Controls were inoculated in the same way using sterile physiological saline $(0.85 \% \mathrm{NaCl})$. Necrosis developed on the cut flowers, leaf and petal tissues 3 days after inoculation. The symptoms induced on cut flowers, 

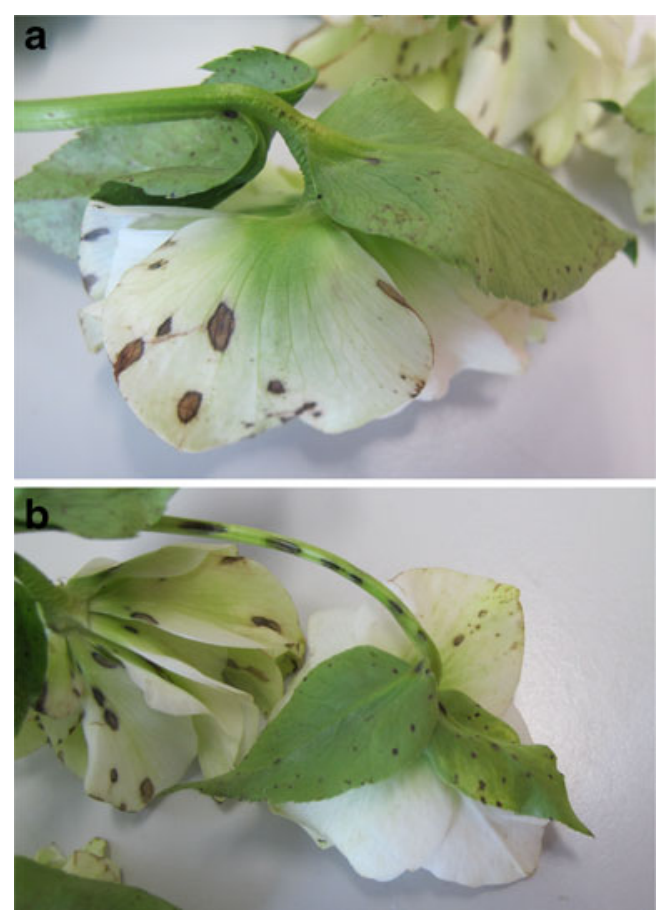

Fig. 1 Hellebore flowers with symptoms caused by Pseudomonas viridiflava: a necrotic petal lesions; b leaf black spot and stem lesions

detached petals and leaves were similar to those caused by natural infections. Bacterial colonies were re-isolated from petal and leaf lesions and identified as $P$. viridiflava, fulfilling Koch's postulates. No disease symptoms developed on the control plants. The pathogenicity tests were performed twice.

The climatic conditions in the Tauranga region at the time disease symptoms were observed were of mild temperatures $\left(12.9-15.9^{\circ} \mathrm{C}\right)$, high humidity $(>90 \%)$ and moderate rainfall ( $>24 \mathrm{~mm}$ per day). P. viridiflava has been found to survive epiphytically on plants for various periods and these conditions are ideal for the bacterium to cause significant plant disease (Young et al. 1988).

$P$. viridiflava is a cosmopolitan phytopathogenic bacterium found on a wide variety of hosts that span at least 31 different species in 14 different families (Bradbury 1987).
Predominantly a leaf spotting pathogen, the bacterium has also been reported to cause leaf rot, leaf blotch, stem necrosis and blossom blight on a number of hosts (Wilkie et al. 1973). In New Zealand, Pseudomonas viridiflava was first found on peas in 1971 (Watson and Dye 1971).

This is the first report of $P$. viridiflava causing a disease of hellebore in New Zealand. Reference cultures have been deposited in the International Collection of Microorganisms from Plants, Landcare Research, Auckland, New Zealand (ICMP 18563, 18564). Worldwide, there are no other reports of $P$. viridiflava on hellebores, with the exception of one website record. The database of plant diseases in Japan (NIAS Genebank 2010) records P. viridiflava as associated with the genus Helleborus in Japan. However, extensive literature searches have not revealed any further details of this association.

\section{References}

Bradbury JF (1987) Pseudomonas viridiflava. CMI Descriptions of Pathogenic Fungi and Bacteria, No 895

Gleason ML, Daughtrey ML, Chase AR, Moorman GW, Mueller DS (2009) Diseases of herbaceous perennials. APS, St Paul, p 281

King EO, Ward MK, Raney DE (1954) Two simple media for the demonstration of pyocyanin and fluorescein. J Lab Clin Med 44:301-307

Lelliott RA, Billing E, Hayward AC (1966) A determinative scheme for the fluorescent plant pathogenic pseudomonads. J Appl Bacteriol 29:470-489

Sarkar SF, Guttman DS (2004) Evolution of the core genome of Pseudomonas syringae, a highly clonal, endemic plant pathogen. Appl Environ Microbiol 70:1999-2012

Watson DRW, Dye DW (1971) Detection of bacterial disease in New Zealand garden pea seed stocks. Plant Dis Report 55:517-21

Wilkie PJ, Dye DW, Watson DRW (1973) Further hosts of Pseudomonas viridiflava. NZ J Agric Res 16:315-23

Young JM, Cheesmur GJ, Welham FV, Henshall WR (1988) Bacterial blight of kiwifruit. Ann Appl Biol 112:91-105

NIAS (2010) Genebank-Database of plant diseases in Japan. Available online at: http://www.gene.affrc.go.jp/databases-micro pl_diseases_en.php. Accessed 20 October 2010. 